\title{
EVALUATION OF PRO-APOPTOTIC ACTIVITY OF Chelidonium majus L. AND/OR GAMMA-RADIATION AGAINST EHRLICH AS CARCINOMA TRANSPLANTED IN MICE
}

\author{
AVALIAÇÃO DA ATIVIDADE PRÓ-APOPTÓTICA DA Chelidonium majus L. E/OU \\ RADIAÇÃO GAMA CONTRA O TUMOR ASCÍTICO DE EHRLICH \\ TRANSPLANTADO EM RATOS
}

\author{
Noura Magdy THABET ${ }^{\mathbf{1}}$; Enas Mahmoud MOUSTAFA ${ }^{\mathbf{1}}$ Iman Hesham EL-KHASHAB $^{2}$ \\ 1. Radiation Biology Department, National Centre for Radiation Research and Technology, Atomic Energy Authority, Egypt. \\ noura_magdy@hotmail.com; 2. Zoology Department, Faculty of Girls, Ain Shams University.
}

\begin{abstract}
This study was to evaluate, the pro-apoptotic activity of ethanolic Chelidonium majus $L$. (CM) leaf extract and/or gamma-radiation in Ehrlich ascites carcinoma (EAC) bearing mice by measuring tumor volume, apoptotic factors (caspase-3, Bcl-2 and Bax proteins, tumor necrosis factor-alpha (TNF- $\alpha$ ), angiogenesis factors (matrix metalloproteinase (MMP-2 and MMP-9); tissue inhibitor of metalloproteinases (TIMP-1), DNA fragmentation, besides histopathological examination. After tumor inoculation, mice received CM (100 $\mathrm{mg} /$ body weight/day) on the $10^{\text {th }}$ day and were exposed to whole body $\gamma$-radiation $(6 \mathrm{~Gy})$ on the $17^{\text {th }}$ day. The data obtained reveales that combining CM with $\gamma$ radiation exposure induce significant regression in tumor growth, up-regulate Bax, caspase-3, TIMP-1 and inhibit Bcl-2, TNF- $\alpha$, MMP-(2 and 9). Cytotoxicity is substantiated by increased DNA-fragmentation (comet assay and DNA content) and histological examination. It could be suggested that combining CM with gamma-radiation increased apoptosis of tumor cells which would help to increase the lifespan of mice.
\end{abstract}

KEYWORDS: Caspase-3. Bcl-2. TIMP-1. DNA fragmentation. Tumor growth.

\section{INTRODUCTION}

Cancer is one of the major causes of death, the general conventional treatment and standard care for clinical oncology remains surgery followed by radiation and/or systemic chemotherapy (ABD ELWAHAB; FOUDA, 2009). Apoptosis is a mode of cell death used by multicellular organisms to remove cells in diverse physiological and pathological settings (BHATTACHARYYA et al., 2003). Modulation of signal transduction pathways, gene expression and arrest in cycle progression or apoptosis suppress tumorigenesis (CHATTERJEE et al., 2013).

Radiation therapy is considered to be one of the most popular and important tools to cure cancer. The killing action of ionizing radiation (X-rays, $\gamma$ rays) is through free radicals produced from the radiolysis of water in the cells. Free radicals by interacting with critical targets like DNA and membranes bring about irreversible damage leading to cell death (HANAFI; MANSOUR, 2010). The study of radio-sensitizers has emerged as a persistent hot spot in radiation oncology (SU et al., 2014).

The herbal drugs have gained attention and popularity because of their negligible toxicity and possibly with a ray of hope that they may replace some of the available toxic antineoplastic drugs. The
Celandine (Chelidonium majus L., CM) is a plant of the Papaveraceae family, known for its richness in specific alkaloids such as sanguinarine, chelidonine, chelerythrine, coptisine or berberine. The plant contains also several secondary metabolites for example isoquinoline. Caffeic acid derivatives, several flavonoids and phenolic acids are present. The plant was shown to possess antitumor, antiinflammatory, anti-arthritic and antimicrobial properties which influence diverse cellular process (NADOVA et al., 2008).

The aim of this study was to evaluate the pro-apoptotic potential of ethanolic extract of $\mathrm{CM}$ leaves and/or gamma radiation in Ehrlich ascites carcinoma (EAC) bearing mice. This goal was achieved by measuring tumor volume, apoptotic factors such as caspase-3, Bcl-2 proteins, Bax proteins and tumor necrosis factor-alpha (TNF- $\alpha$ ), angiogenesis factors including matrix metalloproteinase (MMP-2 and MMP-9) and tissue inhibitor of metalloproteinases (TIMP-1), DNA fragmentation and histopathological examination.

\section{MATERIAL AND METHODS:}

Preparation of Chelidonium majus L. leaves extract

Chelidonium majus $L(\mathrm{CM})$ leaves obtained from local market in Cairo, Egypt were left to dry at 
$20{ }^{\circ} \mathrm{C}$ in a dark place. After drying, the material was fragmented and two gm of dried CM leaves were extracted with $50 \mathrm{ml}$ of ethyl acetate using a Soxhlet apparatus. After $24 \mathrm{~h}$, the infusions were filtered through Whatman No.1 filter paper and the residue re-extracted with $50 \mathrm{ml}$ of ethyl acetate. After $48 \mathrm{~h}$, the process was repeated. The combined supernatants were evaporated to dryness under vacuum at $40{ }^{\circ} \mathrm{C}$ using Rotatory evaporator and stored in sterile sample tubes in a refrigerator at 4 ${ }^{\circ} \mathrm{C}$ (JAKOVLJEVIĆ et al., 2013).

\section{Cytotoxicity Assay:}

The MTT assay to determine the growth and survival of Ehrlich Ascites Carcinoma cells (EAC) was performed in vitro according to Freimoser et al. (1999). The method is based on the reduction of MTT (3- (4, 5 -dimethylthiazol-2yl)-2, 5-diphenyltetrazolium bromide) a water soluble salt to non-water-soluble violet formazan crystals. The amount of these crystals can be determined spectrophotometrically and serve as an estimate for the mitochondrial activity and hence the number of living cells in the sample.

\section{Experimental animals}

Adult female Swiss Albino mice (22-25g) were obtained from the breeding unit of the Egyptian Organization for Biological Products and Vaccines (Cairo) and used in this study. The animals received a commercial standard pellet diet and water ad libitum. Animal care and handling were performed according to the guidelines set by the world health organization, Geneva, Switzerland and approved from the committee for animals care at National Centre for Radiation Research and Technology (NCRRT), Atomic Energy Authority.

\section{Tumor transplantation:}

A cell line of EAC was used in this study. The parent line was supplied from the Egyptian National Cancer Institute (NCI), Cairo University. The EAC cells originated from breast cancer which were adjusted to grow in female Swiss albino mice and maintained by intraperitoneal injection (IP) of $2.5 \times 10^{6}$ EAC cells in the mice. The EAC cells were counted before their IP administration to mice using the bright line haemocytometer and diluted with physiological sterile saline solution. To induce Ehrlich Solid Tumor (EST), $0.2 \mathrm{ml}\left(2.5 \times 10^{6}\right.$ EAC cells) was inoculated intramuscularly in the right thigh of the lower limb of female mouse (GUPTA et al., 2004). The day of EAC inoculation was referred to as day zero of experiment.

\section{Radiation process:}

Whole body $\gamma$-radiation was performing using a Canadian gamma cell-40 $\left({ }^{137} \mathrm{CS}\right)$ at the NCRRT. Cairo, Egypt. Mice were exposed to $6 \mathrm{~Gy}$ applied in one shot dose at a dose rate of $0.49 \mathrm{~Gy} /$ min, on the $17^{\text {th }}$ day after EAC inoculation.

\section{In vivo study:}

70 Female Swiss albino mice were divided randomly into 5 groups. Normal group: 10 mice considered as normal control, E group: 15 mice bearing EAC, $E+R$ group: 15 mice bearing EAC and exposed to $\gamma$-radiation, $E+C M$ group: 15 bearing EAC mice treated with $\mathrm{CM}$ extract at a dose of $100 \mathrm{mg} / \mathrm{kg}$ b.wt (ZAREI et al., 2014) on the $10^{\text {th }}$ day after EAC inoculation and $E+C M+R$ group: 15 bearing EAC mice treated with $\mathrm{CM}$ extract and exposed to $\gamma$-radiation. On the $24^{\text {th }}$ day, animals were fasted for $16 \mathrm{hrs}$ prior to sampling. Then the animals were sacrificed and blood samples and tumor tissues collected for further biochemical and histopathological examinations.

\section{Tumor volume monitoring}

Tumor growth analysis was performed by measuring tumor volume, using vernier calliper on the $8^{\text {th }}, 16^{\text {th }}$ and $23^{\text {rd }}$ day. The volume of solid tumor was calculated using the formula [A X $\left.\mathrm{B}^{2} \mathrm{X} 0: 52\right]$, where $\mathrm{A}$ and $\mathrm{B}$ are the longest and the shortest diameter of tumor, respectively (O'REILLY et al., 1997).

\section{Experimental parameters: \\ Detection of caspase-3 and TIMP-1 gene expression by quantitative real time PCR (qRT- PCR):}

RNA isolation and reverse transcription: RNA was extracted from the tumor tissue homogenate using the RNeasy plus mini kit (Qiagen, Venlo, The Netherlands), according to the manufacturer's instructions. Genomic DNA was removed by DNase-on-column treatment supplied with the kit. The RNA concentration was determined spectrophotometrically at $260 \mathrm{~nm}$ using the NanoDrop ND-1000 spectrophotometer (Thermo Fisher scientific, Waltham, USA) and RNA purity was checked by absorbance ratio at $260 / 280 \mathrm{~nm}$. RNA integrity was assessed by electrophoresis on $2 \%$ agarose gels. One $\mu$ g of RNA was used in the subsequent cDNA synthesis reaction, using the Reverse Transcription System (Promega, Leiden, The Netherlands). Total RNA was incubated at $70{ }^{\circ} \mathrm{C}$ for $10 \mathrm{~min}$ to prevent secondary structures. The RNA was supplemented with $\mathrm{MgCl}_{2}(25 \mathrm{mM})$, RTase buffer (10X), dNTP 
mixture (10mM), oligod(t) primers, RNase inhibitor $(20 \mathrm{U})$ and AMV reverse transcriptase $(20 \mathrm{U} / \mu \mathrm{l})$. This mixture was incubated at $42^{\circ} \mathrm{C}$ for $1 \mathrm{~h}$.

Quantitative real time PCR: qRT-PCR was performed in an optical 96-well plate with an ABI PRISM 7500 fast sequence detection system (Applied Biosystems, Carlsbad, California) and universal cycling conditions of 40 cycles of $15 \mathrm{~s}$ at $95^{\circ} \mathrm{C}$ and $60 \mathrm{~s}$ at $60^{\circ} \mathrm{C}$ after an initial denaturation step at $95^{\circ} \mathrm{C}$ for $10 \mathrm{~min}$. Each $10 \mu \mathrm{l}$ reaction mixture contained $5 \mu \mathrm{l}$ SYBR Green Master Mix (Applied Biosystems), $0.3 \mu \mathrm{l}$ gene-specific forward and reverses primers $(10 \mu \mathrm{M}), 2.5 \mu \mathrm{l} \mathrm{cDNA}$ and $1.9 \mu \mathrm{l}$ nuclease-free water. The sequences of PCR primer pairs used for each gene are shown in Table 1. Data were analyzed with the ABI Prism sequence detection system software and quantified using the v1.7 Sequence Detection Software from PE Biosystems (Foster City, CA). Relative expression of studied genes was calculated using the comparative threshold cycle method. All values were normalizing to the endogenous control GAPDH (LIVAK; SCHMITTGEN, 2001).

Table 1. Primer sequences used for RT-PCR

\begin{tabular}{ll}
\hline \multicolumn{1}{c}{ Primer } & \multicolumn{1}{c}{ Sequence } \\
\hline Caspase-3 & Forward:5'-ATGGACAACAACGAAACCTC -3' \\
& Reverse:5'-TTAGTGATAAAAGTACAGTTCTT -3' \\
\hline TIMP-1 & Forward primer 5'-GCATCTGGCATCCTCTTGTT-3' \\
& Reverse primer 5'-TGGGGAACCCATGAATTTAG-3' \\
\hline GAPDH & Forward: 5'- CTCCCATTCTTCCACCTTTG-3' \\
& Reverse: 5'- CTTGCTCTCAGTATCCTTGC-3' \\
\hline
\end{tabular}

\section{Determination of Serum MMP-2 and -9}

Determination of MMP-2 and MMP-9 was carried out using polyacrylamide gel electrophoresis according to Birkedal-Hansen and Taylor (1982). MMP-2 and MMP-9 protein levels are quantitatively assessed by vertical slap SDS-PAGE containing $1 \mathrm{mg} / \mathrm{ml}$ type B gelatine as a substrate for the enzymes. MMP-2 and MMP-9 detected on the SDS gel as transparent bands. The serum samples were used without boiling, MMP-2 (72 $\mathrm{kDa})$ and MMP-9 (92 $\mathrm{kDa})$ proteins can be defined on slap gel by their gelatinolytic enzyme activity, which appeared as bands on background and compared to standard human purified collagenase IV (Sigma Co., USA) and a protein marker (Sigma Co., USA) the gel system adapted as described by Davis (1964).

\section{Single cell gel electrophoresis (SCGE) Comet assay}

The alkaline comet assay was performed on tumor tissue. Tissues were dissected and homogenized in ice-cold buffer $(0.075 \mathrm{M} \mathrm{NaCl}$ and $0.024 \mathrm{M} \mathrm{Na}_{2}$ EDTA; $1 \mathrm{~g}$ tissue $/ 1 \mathrm{ml}$ buffer). The comet assay was carried out under alkaline conditions, as described by Singh et al. (1988). The slides were stained with ethidium bromide $(20 \mathrm{lg} /$ $\mathrm{ml}$ ) and examined using a $250 \mathrm{X}$ magnification fluorescence microscope (Zeiss, Jena, Germany) equipped with an excitation filter of $515-560 \mathrm{~nm}$ and a barrier filter of $590 \mathrm{~nm}$. A computer-based image analysis system (Comet Assay II; Perceptive Instruments Ltd., Suffolk, UK) was used. A total of
50 comets per sample per animal were scored, and data were pooled (250 comets per group). Tail intensity (\% DNA in the comet tail) and tail length (expressed in micrometres) were evaluated. The values of tail length were used for the determination of the long-tailed nuclei count as described previously (BENKOVIC'et al., 2009).

\section{Histopathological Estimation of Tumor}

Portions of the formalin-fixed tumor were setting in paraffin, sectioned and stained with hematoxylin and eosin stain (H\&E) for histopathological examination under a light microscope (BANCROFT et al., 1996).

\section{DNA content}

Total protein was detected by mercurybromophenol blue stain (MAZIA et al., 1953) and DNA content was examined by Feulgen reaction (PEARSE, 1985).

\section{Immunohistochemistry}

Immunostaining technique of TNF- $\alpha, \mathrm{Bcl}-2$ and Bax proteins were tested by the method of Teerds and Dorrington (1995).

\section{Statistical Analysis}

The data were statistically analyzed using SPSS computer Program (v.17). The results were presented as Mean \pm SE. The differences between mean values were analysed by one way analysis of variance (ANOVA test) followed by LSD as a post 
hoc test for multiple comparisons. All statements of significance were based on probability of $\mathrm{P} \leq 0.05$.

\section{RESULTS}

\section{Cytotoxicity Assay:}

To show the effect of $\mathrm{CM}$ on cell viability, EAC cells were incubated with $\mathrm{CM}$ at different concentration $(50,75,100$ and $150 \mu \mathrm{g} / \mathrm{mL})$ for 48 hours. The results revealed that, $\mathrm{CM}$ at a dose of $100 \mu \mathrm{g} / \mathrm{mL}$ was the most efficient in decreasing the viability of EAC cells (Table 2).

Table 2. Effect of different concentrations of CM extract on the cell viability of EAC cells

\begin{tabular}{cccccc}
\hline Groups & EAC & $\begin{array}{c}\text { CM (50 } \\
\mu \mathrm{g})+ \text { EAC }\end{array}$ & $\begin{array}{c}\text { CM }(\mathbf{7 5} \\
\mu \mathrm{g})+\mathbf{E A C}\end{array}$ & $\begin{array}{c}\text { CM }(\mathbf{1 0 0} \\
\mu \mathrm{g})+\mathbf{E A C}\end{array}$ & $\begin{array}{c}\text { CM }(150 \\
\mu \mathrm{g})+\mathbf{E A C}\end{array}$ \\
\hline $\begin{array}{c}\text { Means } \pm \text { SE } \\
\text { \%of cell } \\
\text { viability }\end{array}$ & $1.75 \pm 0.036$ & $0.57 \pm 0.01^{\mathrm{a}}$ & $0.4 \pm 0.018^{\mathrm{a}}$ & $0.17 \pm 0.017^{\mathrm{a}}$ & $0.37 \pm 0.014^{\mathrm{a}}$ \\
& $100 \%$ & $32.57 \%$ & $22.86 \%$ & $9.71 \%$ & $21.14 \%$ \\
\hline
\end{tabular}

Values were represented as mean \pm SE. a: Significant compared to EAC group $(\mathrm{P}<0.05)$

\section{Tumor Volume:}

The results revealed that, treatment of EAC bearing mice with $\mathrm{CM}$ and/or gamma-radiation caused a marked decrease in tumor volume compared to E-group (Figure 1).

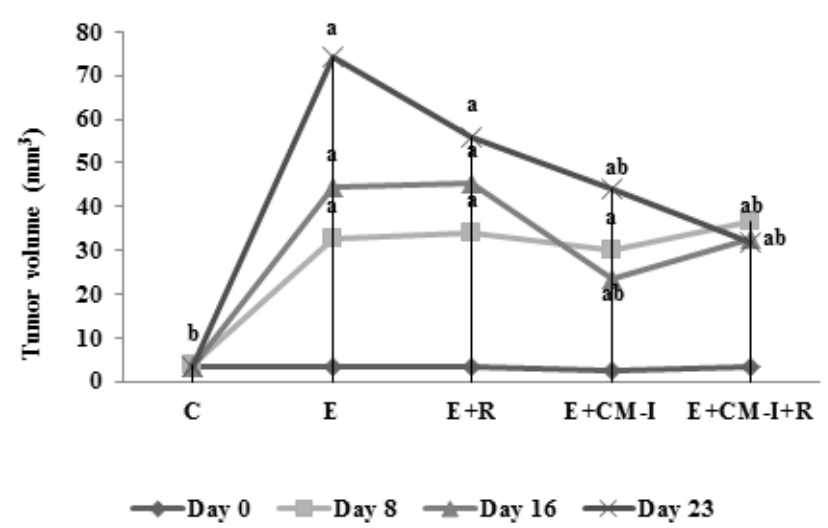

Figure 1. Effect of administration of CM $(100 \mathrm{mg} / \mathrm{kg}$ b.wt $)$ and/or exposed to $\gamma$-radiation on tumor volume in $\mathrm{E}$ treated mice. Values were represented as mean $\pm \mathrm{SE}(\mathrm{n}=10)$. a: Significant compared to the control group $(\mathrm{P}<0.05)$. b: Significant compared to E group $(\mathrm{P}<0.05)$.

\section{Detection of Caspase-3 and TIMP-1 Gene} Expression:

In the present study, the results showed that in the control group the gene expression of caspase3 and TIMP-1 was $1 \pm 0.13$ fold and $5.03 \pm 0.59$ fold, respectively. In E-group, the data revealed nonsignificant change in gene expression of caspase-3 mRNA compared with control. But in EAC mice treated with $\mathrm{CM}$ and/or exposed to $\gamma$-radiation, it was significantly higher compared to E-group $(\mathrm{P}<$ 0.05 ) (Table 3). On the other hand, the results displayed a significant decrease $(\mathrm{P}<0.05)$ in TIMP-1 mRNA in E-group compared with control group. Meanwhile, a significant increase in TIMP-1 mRNA was recorded in $\mathrm{E}+\mathrm{CM}$ and $\mathrm{E}+\mathrm{CM}+\mathrm{R}$ groups compared to E-group $(\mathrm{P}<0.05)$ (Table 3).

Table 3. Effect of CM and/or $\gamma$-radiation on gene expression of caspase-3 and TIMP-1

\begin{tabular}{lcc}
\hline \multicolumn{1}{c}{ Group } & Caspase-3 & TIMP-1 \\
\hline $\mathbf{C}$ & $0.98 \pm 0.027^{\mathrm{a}}$ & $5.03 \pm 0.240^{\mathrm{a}}$ \\
$\mathbf{E}$ & $1.22 \pm 0.069^{\mathrm{a}}$ & $2.43 \pm 0.164^{\mathrm{b}}$ \\
$\mathbf{E}+\mathbf{R}$ & $5.85 \pm 0.103^{\mathrm{b}}$ & $2.90 \pm 0.141^{\mathrm{b}}$ \\
$\mathbf{E}+\mathbf{C M}$ & $4.67 \pm 0.198^{\mathrm{c}}$ & $8.65 \pm 0.329^{\mathrm{c}}$ \\
$\mathbf{E}+\mathbf{C M}+\mathbf{R}$ & $11.75 \pm 0.290^{\mathrm{d}}$ & $10.18 \pm 0.181^{\mathrm{d}}$ \\
\hline
\end{tabular}

Values are means \pm SE $(n=10)$; Values with different superscripts significantly different, at $\mathrm{P} \leq 0.05$;Values with same superscripts notsignificantly different, at $\mathrm{P} \leq 0.05$. 


\section{Detection of serum MMP-(2 and 9) by gel electrophoresis:}

The experimental data for MMP-(2 and 9) in different mice groups is presented in Table 4 and Figure 2. The concentrations of MMP-2 and MMP-9 in active form were $117.12 \pm 1.26$ and $86.35 \pm 0.431$ $\mathrm{U} / \mathrm{mg}$ proteins in control group, respectively. A significant increase in MMP-(2 and 9) concentration was observed in samples isolated from the serum of E-groups as compared to control group. The treatment with $\mathrm{CM}$ and/or $\gamma$-radiation induced a remarkable modulation in MMP-(2and9) concentration as compared to E-group. The qualitative analysis of the zymographs showed that the majority of E-groups serum showed gelatinolytic bands for both the active enzymatic forms of MMP2 and MMP-9 when compared with normal serum (Figure. 2).

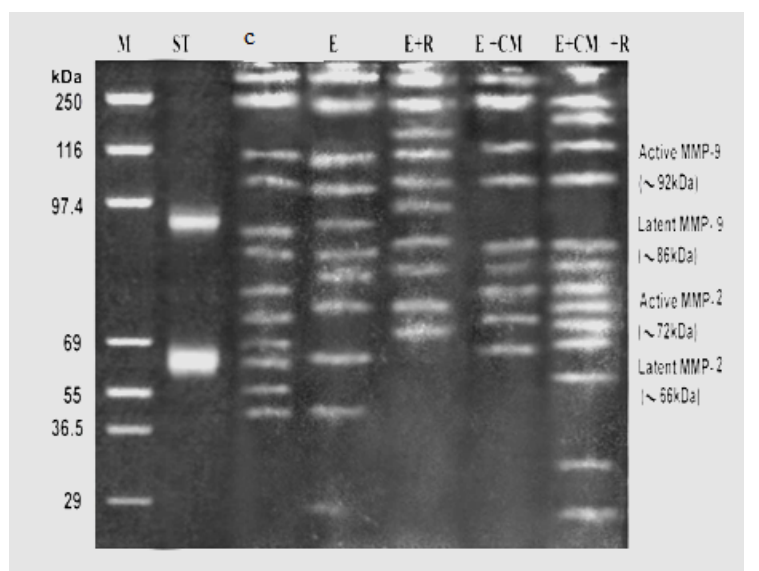

Figure 2. Zymograph of Matrix metalloproteiases (Gelatinase A; MMP-2 and Gelatinase B; MMP-9) active and inactive forms (lane M) Marker proteins $(<300 \mathrm{Ka})$; (lane ST) Standards of purified MMP-2 and MMP-9; (C) Serum of normal control mice; (E) Serum of EAC mice; (E+R) Serum of EAC irradiated mice; and $(\mathrm{E}+\mathrm{CM})$ Serum of EAC treated with $\mathrm{CM}$ mice; $(\mathrm{E}+\mathrm{CM}+\mathrm{R})$ Serum of EAC treated with CM irradiated mice.

Table 4. Effect of CM and/or $\gamma$-radiation on serum MMP-(2 and-9) (U/mg protein) in active forms analyzed by Gelatin zymography

\begin{tabular}{|c|c|c|}
\hline Group & MMP2-active & MMP9-active \\
\hline $\mathrm{C}$ & $117.12 \pm 1.26^{\mathrm{a}}$ & $86.35 \pm 0.431^{\mathrm{a}}$ \\
\hline $\mathbf{E}$ & $244.19 \pm 1.25^{\mathrm{b}}$ & $195.68 \pm 0.815^{b}$ \\
\hline $\mathbf{E}+\mathbf{R}$ & $192.48 \pm 1.38^{\mathrm{c}}$ & $167.75 \pm 0.811^{\mathrm{c}}$ \\
\hline $\mathbf{E}+\mathbf{C M}$ & $175.30 \pm 0.62^{\mathrm{d}}$ & $157.60 \pm 0.611^{\mathrm{d}}$ \\
\hline $\mathrm{E}+\mathrm{CM}+\mathrm{R}$ & $127.58 \pm 0.43^{\mathrm{e}}$ & $114.33 \pm 0.745^{\mathrm{e}}$ \\
\hline
\end{tabular}

\section{Comet Assay:}

The results displayed the DNA strand breaks by $\mathrm{CM}$ or ionizing radiation, in isolated lymphocyte cells, whereas damaged nuclei consist of a head with DNA migrating into the tail region because of extensive single-strand breaks. The results showed normal nuclei in the control group
(Figure 3-C), different levels of DNA damage in Egroup (Figure 3-1), and apoptotic nucleus in tumor cells in $\mathrm{E}+\mathrm{R}, \mathrm{E}+\mathrm{CM}$ and $\mathrm{E}+\mathrm{CM}+\mathrm{R}$ groups (Figure 3-2, 3-3 and 3-4), respectively. Average background DNA damage in lymphocytes was significantly higher in the $\mathrm{E}+\mathrm{CM}+\mathrm{R}$ group than those of E-group (Table 5). 

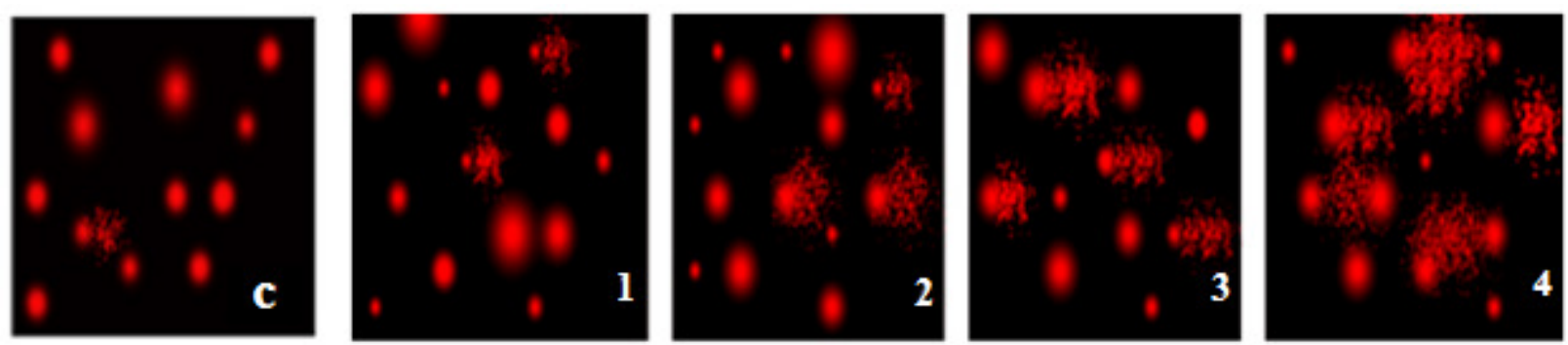

Figure 3. Appearances of comet in different types of mice tumour tissue. All photomicrographs are acquired by image analysis system Comet Assay II (Perceptive Instruments Ltd., Suffolk, UK) under magnification 250x. Stained with ethidium bromide.

Table 5. Comet assay expressed as tail length

\begin{tabular}{lcc}
\hline & Group & Tail length $(\boldsymbol{\mu m})$ \\
\hline Control & $0.78 \pm 0.005^{\mathrm{a}}$ \\
$\mathbf{E}$ & $1.13 \pm 0.044^{\mathrm{b}}$ \\
$\mathbf{E}+\mathbf{R}$ & $3.12 \pm 0.030^{\mathrm{c}}$ \\
$\mathbf{E}+\mathbf{C M}$ & $3.57 \pm 0.018^{\mathrm{d}}$ \\
$\mathbf{E}+\mathbf{C M}+\mathbf{R}$ & $4.27 \pm 0.064^{\mathrm{e}}$ \\
\hline
\end{tabular}

\section{Histological Studies:}

Solid tumor in muscle tissue

Histopathological examination of the solid tumor in muscle section of E-group, showed tumor cells characterized by their large, round and polygonal with polymorphic shape, basophilic cytoplasm, hyper-chromatic nuclei and mitosis (Figure 4A) and many islets of tumor cells surrounding muscular fibres (Figure 4B). It was observed also that, islets of tumor cells were enclosed by necrotic rupture muscle fibres replacing the normal fibres (Figure 4C) and such islets were invaginated by newly formed blood capillaries "angiogenesis" surrounded by a thick zone of tumor cells (Figure 4D). Nevertheless, solid tumor of E+R and $\mathrm{E}+\mathrm{CM}$ groups showed small regression in volume of islets of tumor cells that were surrounded by muscular tissue capsule (Figure $5 \mathrm{~A}$ and $5 \mathrm{~B}$, respectively). While, the solid tumor of $\mathrm{E}+\mathrm{CM}+\mathrm{R}$ group, showed more regression in tumor volume than the previous groups (Figure 5C).

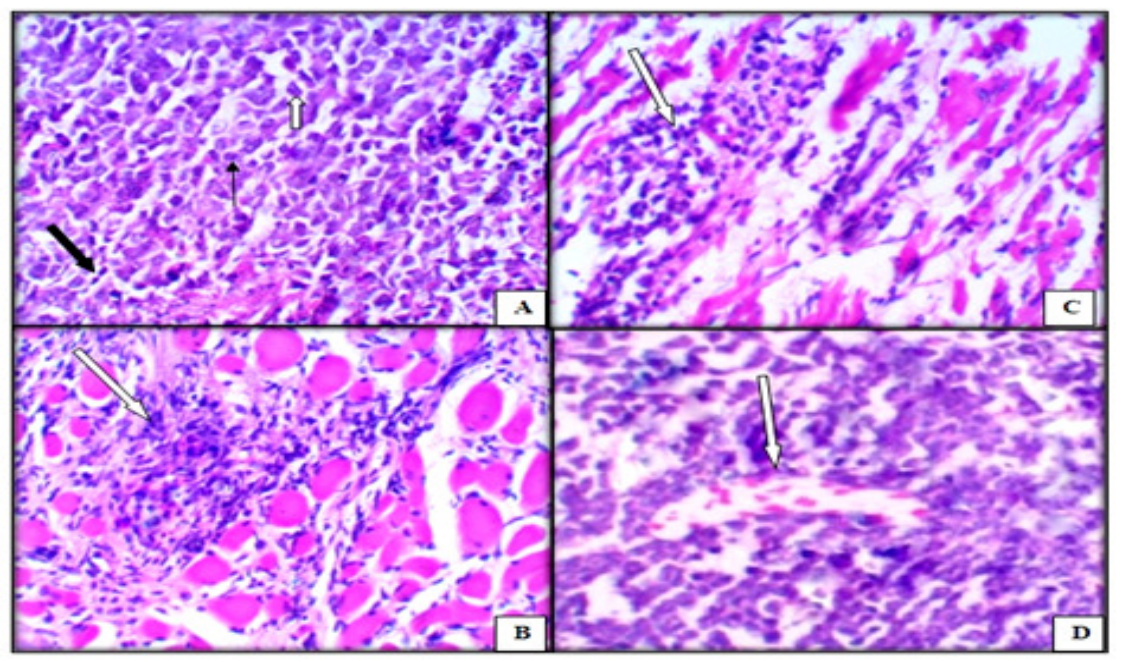

Figure 4. Photomicrograph of solid tumour section showing: (A) the tumour cells characterized by their large, round (arrow) and polygonal structure (white arrow) with polymorphic shape, basophilic cytoplasm, hyperchromatic nuclei and mitotic activity (black arrow) (H\&Ex 400). (B): Numerous islets of tumour cells (white arrow) surrounded muscular fibers (H\&Ex 200). (C): islets of tumour cells(white arrow)were enclosed by necrotic ruptured muscle fibers replacing the normal fibers. (D): islets of tumour cells were invaginated by newly formed blood capillaries "angiogenesis" (white arrow) surrounded with a thick zone of tumour cells (H\&E× 400$)$. 


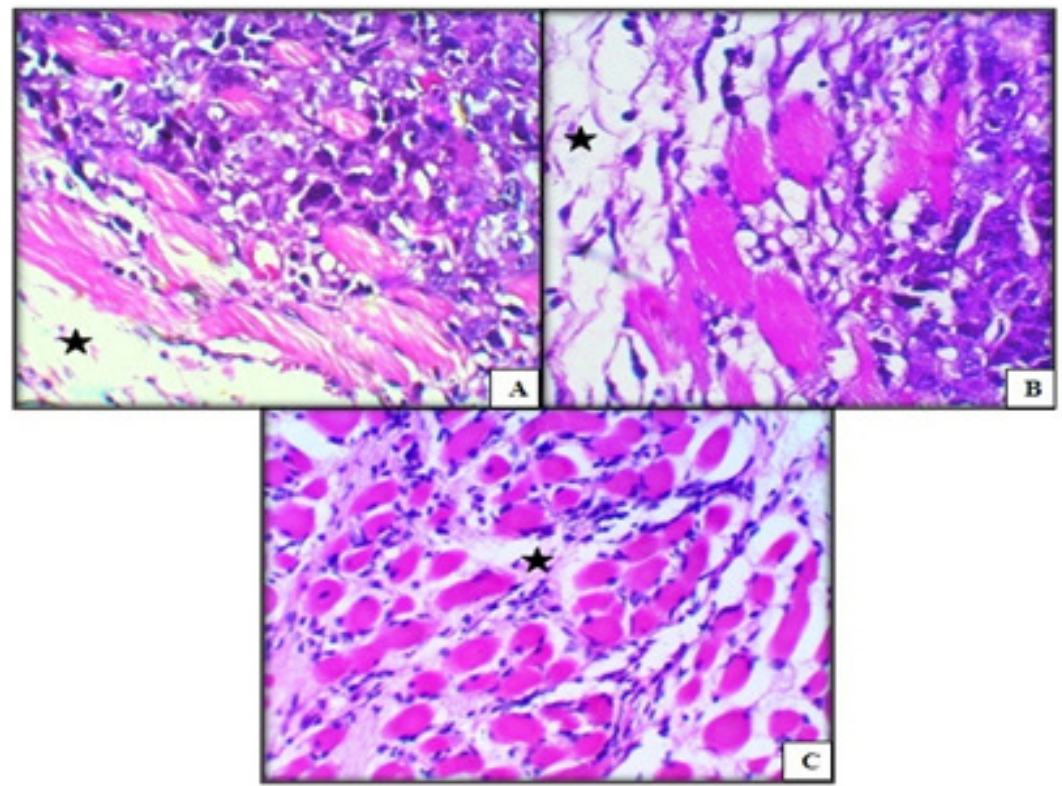

Figure 5. Photomicrograph of solid tumour section treated with $\gamma$-radiation (A) or CM (B) showed small regression in volume of islets of tumour cells (black star) that were surrounded by muscular tissue capsule $(\mathrm{H} \& \mathrm{E} \times 400)$. $(\mathrm{C})$ : group treated with $\gamma$-radiation and $\mathrm{CM}$ showed more regression in tumour volume (black star) $(\mathrm{H} \& \mathrm{E} \times 400)$.

\section{DNA content in solid tumor:}

Solid tumor sections of E-group showed DNA chromatin forms well-defined irregular clumps with variable sizes, shapes and sharp pointed projections as well as tumor nuclei with multiple nucleoli and irregular nuclear membrane (Figure $6 \mathrm{~A})$. On the other hand, $\mathrm{E}+\mathrm{CM}+\mathrm{R}$ group revealed a few neoplastic cells and some apoptotic cells identified by DNA fragmentation (Figure 6B).

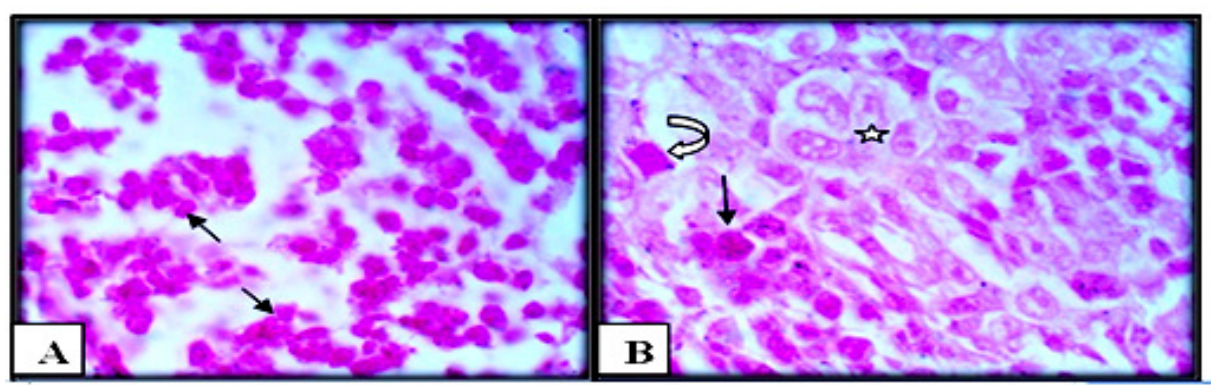

Figure 6: Photomicrograph for the determination of DNA content in solid tumour tissue (A) showed DNA chromatin forms well-defined irregular clumps with variable sizes, shapes and sharp pointed projections (arrow) and tumour nuclei with multiple nucleoli and irregular nuclear membrane (arrow) in (E) group. (B) Showed some neoplastic cells (round arrow), some apoptotic cells illustrated by DNA fragmentation and some dead cells (white star) in $\mathrm{E}+\mathrm{CM}+\mathrm{R}$.

\section{Immunohistochemistry \\ TNF- $\alpha$}

Immunostaining of TNF- $\alpha$ was identified by the brown coloration in the cytoplasm of tumor tissue. Its overexpression elevation is clearly indicated in E-group (Figure 7A and 7B). Whereas, in $\mathrm{E}+\mathrm{R}$ (Figure $7 \mathrm{C}$ and $7 \mathrm{D}$ ) and $\mathrm{E}+\mathrm{CM}$ (Figure7E and 7F) groups, TNF- $\alpha$ expression was slightly reduced in the cytoplasm of solid tumor cells compared to the previous group. While, in $\mathrm{E}+\mathrm{CM}+\mathrm{R}$ group (Figure $7 \mathrm{G}$ and $7 \mathrm{H}$ ) TNF- $\alpha$ expression was highly reduced compared to the previous groups. 


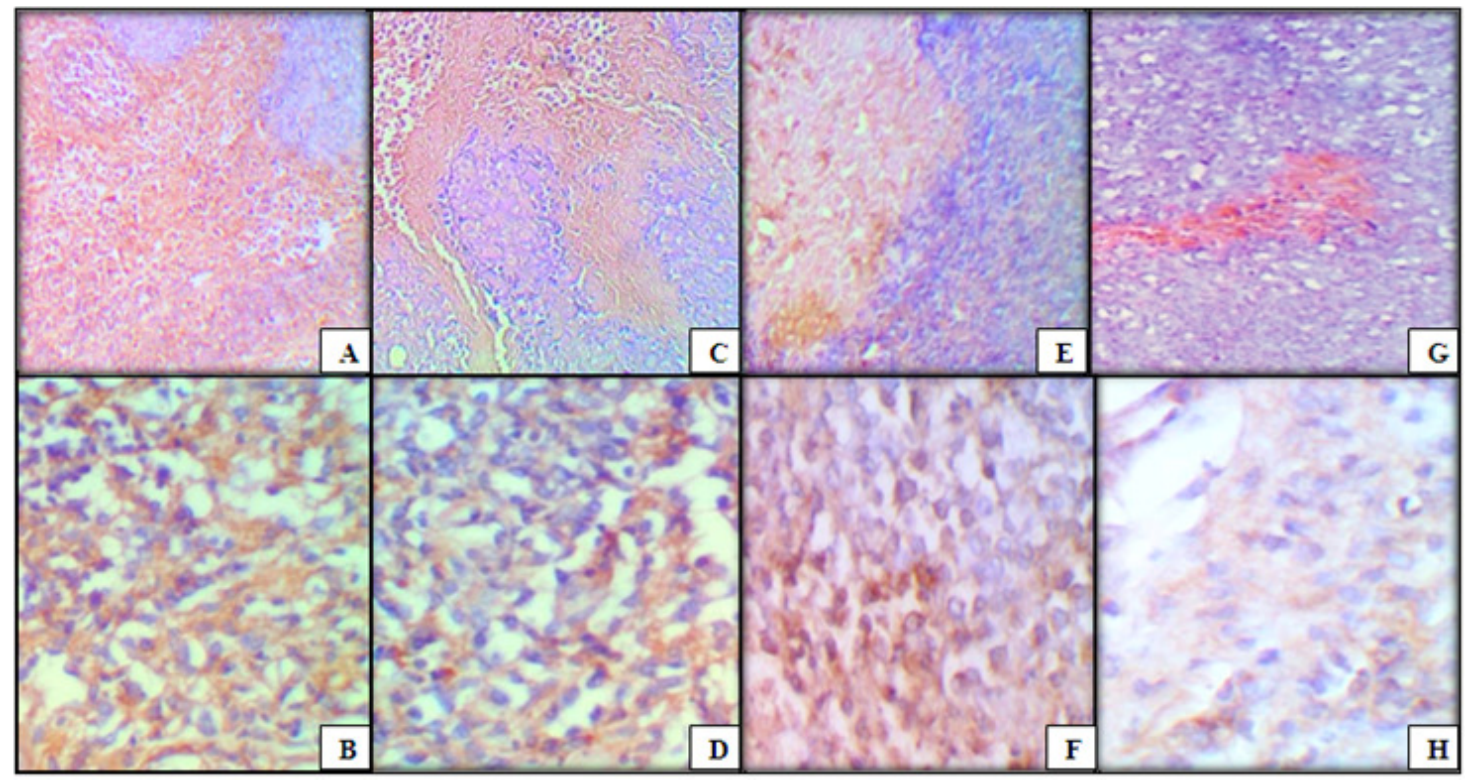

Figure 7. Immunohistochemical staining with TNF- $\alpha$ : $(A$ and $B)$ in E-group, $(C$ and $D)$ in E+Rgroup, $(E$ and $F)$ in $\mathrm{E}+\mathrm{CM}$ group and $(\mathrm{G}$ and $\mathrm{H})$ in $\mathrm{E}+\mathrm{CM}+$ Rgroup. $(\mathrm{A}),(\mathrm{C}),(\mathrm{E})$, (G) (magnification $\times 100)$. (B), (D), $(\mathrm{F}),(\mathrm{H})$ (magnification $\times 1000)$.

\section{Bax}

Accumulation of Bax protein was identified by a brown coloration in the cytoplasm of tumor tissue. Down expression of Bax protein in the Egroup are detected (Figure $8 \mathrm{~A}$ and $8 \mathrm{~B}$ ). While, the $\mathrm{E}+\mathrm{R}($ Figure $8 \mathrm{C}$ and $8 \mathrm{D}$ ) and $\mathrm{E}+\mathrm{CM}$ (Figure 8E and
8F) groups revealed slightly elevation in Bax protein compared with the previous group. Whereas, the $\mathrm{E}+\mathrm{CM}+\mathrm{R}$ group (Figure $8 \mathrm{G}$ and $8 \mathrm{H}$ ) showed overexpression of Bax protein in the cytoplasm of tumor tissue compared with the previous groups.

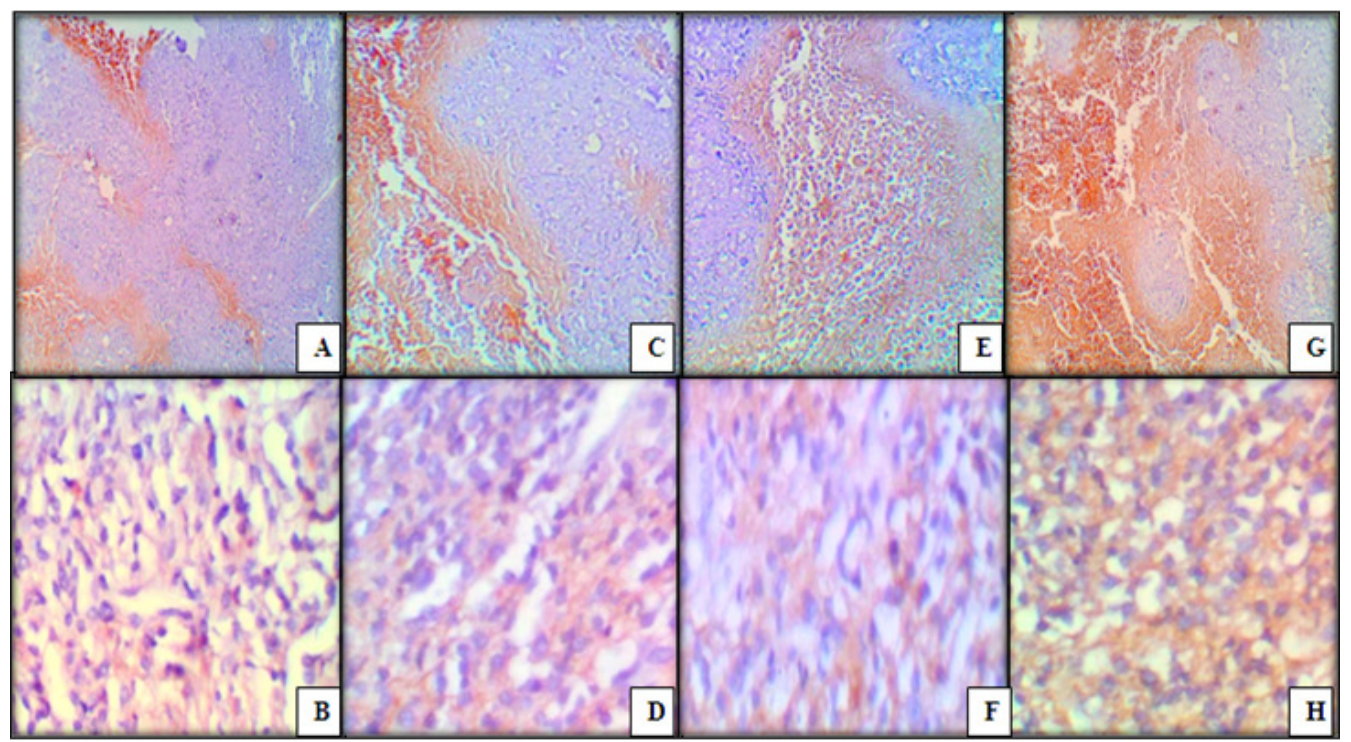

Figure 8. Immunohistochemical staining with Bax: $(A$ and $B)$ in E-group, $(C$ and $D)$ in $E+R$ group, $(E$ and $F)$ in $\mathrm{E}+\mathrm{CM}$ group and $(\mathrm{G}$ and $\mathrm{H})$ in $\mathrm{E}+\mathrm{CM}+\mathrm{R}$ group. $(\mathrm{A}),(\mathrm{C}),(\mathrm{E}),(\mathrm{G})$ (magnification $\times 100)$. (B), (D), $(\mathrm{F}),(\mathrm{H})$ (magnification $\times 1000)$.

\section{Bcl2}

The accumulation of $\mathrm{Bcl}-2$ protein is indicated by a brown coloration in the cytoplasm of tumor tissue. Strong immune reactivity for $\mathrm{Bcl}-2$ was detected in the E-group (Figure 9A and 9B). While, the E+R (Figure 9C and 9D) and $\mathrm{E}+\mathrm{CM}$ groups (Figure 9E and 9F) revealed weak expression in $\mathrm{Bcl}-2$ protein compared with the previous group. On the other hand, strong down expression of $\mathrm{Bcl}-2$ protein was observed in the $\mathrm{E}+\mathrm{CM}+\mathrm{R}$ group (Figure $9 \mathrm{G}$ and $9 \mathrm{H}$ ) compared with the previous groups. 


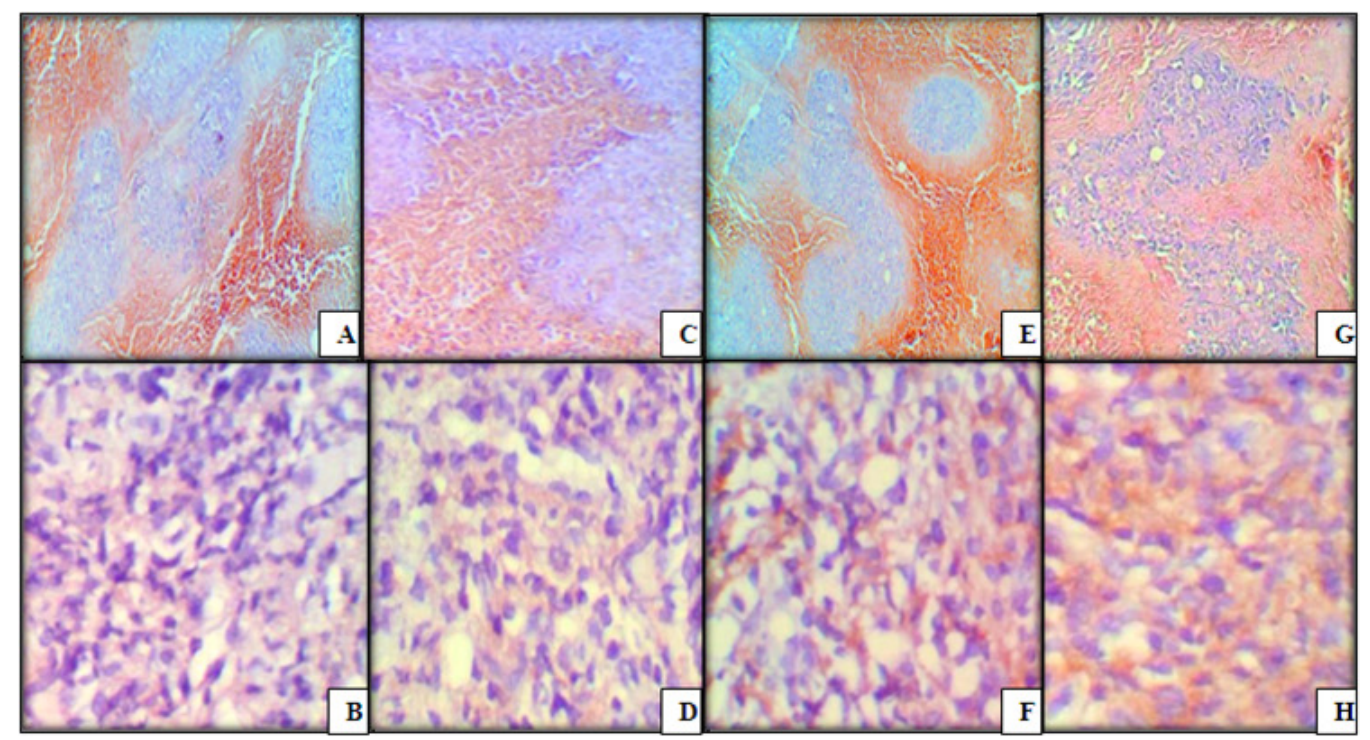

Figure 9. Immunohistochemical staining with Bcl-2: $(\mathrm{A}$ and $\mathrm{B})$ in E-group, $(\mathrm{C}$ and $\mathrm{D})$ in $\mathrm{E}+\mathrm{R}$ group, $(\mathrm{E}$ and $\mathrm{F})$ in $\mathrm{E}+\mathrm{CM}$ group and $(\mathrm{G}$ and $\mathrm{H})$ inE $+\mathrm{CM}+\mathrm{R}$ group. $(\mathrm{A}),(\mathrm{C}),(\mathrm{E}),(\mathrm{G})($ magnification $\times 100)$. (B), (D), $(\mathrm{F}),(\mathrm{H})($ magnification $\times 1000)$.

\section{DISCUSSION}

In the present study, the results of E-group revealed increased angiogenesis and depressed apoptosis. the resistance of cancer cells to TNF- $\alpha$ induced death based on the fact that TNF- $\alpha$ induced survival signals such as nuclear factor- $\kappa \mathrm{B}(\mathrm{NF}-\kappa \mathrm{B})$ that blunt the apoptotic pathway and activated the survival pathway (WAJANT et al., 2003). In a concurrent study, Abdel-Rahman and Kabel (2012) noted that, immune-staining of TNF- $\alpha$ and Bcl-2 showed over expression in the group of mice bearing tumour while down expression of Bax was observed in the same group. Meanwhile, Sun et al. (2010) reported that cancer cells down-regulate TIMP and produce extracellular MMP-inducer, a cell surface glycoprotein, which directly stimulates fibroblasts to produce MMP-1, 2, 3, 9 and 14. Changes occurring in the biochemical parameters were confirmed by the histopathological observation. The histopathological examination showed islets of tumor cells were invaginated by newly formed blood capillaries "angiogenesis". Active angiogenesis are identified by the presence of irregular blood capillaries to supply the tumours (GROSSMAN; MCNEIL, 2012). This leads to activation of NF- $\mathrm{KB}$ in cancer cells, which regulate transcription of genes involved in cell proliferation, anti-apoptosis and invasion. Activation of NF- $\mathrm{KB}$ induces tumour growth and reduces cytokinesinduced apoptosis (AGGARWAL et al., 2006) which is supported by the previous findings of Salah (2011) and Hanafi (2012). the disappearance of dna fragments in e-group, postulates loss of apoptosis ended by tumour development. Ghobrial et al. (2005) reported that types of cancers characterized by defects in apoptosis leads to immortal clones of cells.

$\mathrm{CM}$ and/or $\gamma$-radiation treatment, in the present study, revealed regression in tumour volume. It is well known that exposure of mammalian cells to ionizing radiation induces several types of damage to DNA, including double and single-strand breaks, base and sugar damage, as well as DNA-DNA and DNA-protein cross-links. During radiotherapy, ionizing radiation interacts with biological system and induces excessive oxygen free radicals or reactive oxygen species (ROS) which attack cellular DNA, proteins and membrane lipids. This leads to significant cellular damage by increasing apoptotic cells $\%$ and decreasing the mitochondrial membrane potential (BEGUM et al., 2012). Further, Kitada et al. (1996) showed that exposure of mice to $\gamma$-radiation results in a rapid elevation in the levels of the Bax protein in lymphoid cells. However, ionizing radiation induces mitotic cell death in dividing cells and activates pathways that lead to death by apoptosis in interphase cells and differentiated cells. In addition, Lawrence et al. (2008) reported that, $\gamma$-radiation therapy shrink tumour and kill cancer cells through damaging their DNA directly or creates free radicals within the cells to damage the DNA. Susskind et al. (2003) found that, radiation provokes a sharp decrease in MMP-9 within 2 weeks, without change in TIMP-1, and that decrease reflects reduced 
neutrophil and macrophage involvement in the neoplastic process.

The modulation of tumor by CM treatment could be referred to its anti-inflammatory, antimicrobial, antiviral and antitumor activities. In addition, CM showed an anti-angiogenesis effect that was dependent on decreased activity of migration, inhibition of VEGF and MMP-2,-9 and increase of TIMP release (KIM et al., 2011). Beside and Park et al. (2015) found that, CM extract induce cell cycle arrest, activation of the caspase-3 dependent pathway, blocking of $\mathrm{NF}-\kappa \mathrm{B}$ activation as well as significantly decrease the mRNA levels of Bcl-2, survivin and increase Bax expression. Moreover, sanguinarine isolated from CM, suppresses $\mathrm{NF}-\kappa \mathrm{B}$ and sensitizes cancer cells to apoptosis by inducing ROS generation and activate TNF-related apoptosis-inducing ligand (Gupta et al., 2010). In addition, Choi et al. (2009) found that, sanguinarine down regulates MMP-2 and MMP-9.

It is concluded that, $\mathrm{CM}$ as well as $\gamma$ radiation decrease tumor growth by initiating apoptosis, distribution of nuclear DNA fragmentation and histopathological investigations besides up-regulating Bax while down-regulating Bcl-2, by activation of caspase- 3 and inhibition of TNF- $\alpha$, by releasing TIMP-1 and preventing MMP$2,-9$. The combination of both $\mathrm{CM}$ and $\gamma$-radiation has a better anti-tumor effect against tumour growth than $\mathrm{CM}$ or $\gamma$-radiation alone.

RESUMO: Este estudo foi realizado para avaliar a atividade pró-apoptótica do extrato etanólico da folha da Chelidonium majus L. (CM) e/ou radiação gama no tumor ascítico de Ehrlich tendo ratos para a medição do volume do tumor, fatores apoptóticos (caspase-3, proteínas Bcl-2 e Bax, fator de necrose tumoral (TNF- $\alpha$ )), fatores angiogênicos (metaloproteinase matriz (MMP-2 e MMP-9)); inibidor tecidual de metaloproteinase (TIMP-1), fragmentação de DNA, além de exame histopatológico. Depois da inoculação do tumor, os ratos receberam CM $100 \mathrm{mg} / \mathrm{peso}$ corporal/dia no $10^{\circ}$ dia e tiverem o corpo completo exposto a radiação gama (6Gy) no $17^{\circ}$ dia. Os dados obtidos revelam que combinar CM com exposição à radiação gama induz a uma regressão significativa no crescimento do tumor, regula positivamente Bax, caspase-3, TIMP-1 e inibe Bcl-2, TNF- $\alpha$, MMP-(2 e 9). Citotoxicidade é substanciada pelo aumento da fragmentação do DNA (ensaio cometa e conteúdo de DNA) e exame histopatológico. Poderia ser sugerido que combinar CM com radiação gama aumentou a apoptose das células tumorais o que ajudaria a aumentar a expectativa de vida dos ratos.

PALAVRAS-CHAVE: Caspase-3. Bcl-2. TIMP-1. Fragmentação do DNA. Crescimento tumoral.

\section{REFERENCES}

ABD EL-WAHAB, S. M. AND FOUDA, F. M. Histological and histochemical study on the effect of Ehrlich ascites carcinoma on the liver and kidney of mice and the possible protective role of tetrodotoxin. Egyptian Journal of Biology, v.11, p. 13-25, 2009. http://dx.doi.org/10.1016/j.jnci.2012.08.001

Abdel-Rahman, M. N. AND Kabel, A. M. Comparative study between the effect of methotrexate and valproic acid on solid Ehrlich tumor. Journal of the Egyptian National Cancer Institute, v. 24, p. 161-167, 2012.

AGGARWAL, S.; ICHIKAWA, H. AND TAKADA, Y. Curcumin (diferuloylmethane) down-regulates expression of cell proliferation and antiapoptotic and metastatic gene products through suppression of Ikappa B alpha kinase and Akt activation. Molecular Pharmacology, v. 69, p.195-206, 2006.

BANCROFT, J. D. AND STEVENS, A. (). The haematoxylin and eosin. Theory and practice of histological techniques. $4^{\text {th }}$ Ed, Ch 6, Churchill Livingstone, London, New York and Tokyo, 1996. 99-112 p.

BEGUM, N.; PRASAD, N. G.; KANIMOZHIA, A. Q. AND HASAN, S. Apigenin ameliorates gamma radiation-induced cytogenetic alterations in cultured human blood lymphocytes. Mutation Research, v. 747, p. 71- 76, 2012. http://dx.doi.org/10.1016/j.mrgentox.2012.04.001

BENKOVIĆ, V.; KNEZEVIĆ, AH.; DIKIĆ, D.; LISICIĆ, D.; ORSOLIĆ, N.; BASIĆ, I. AND KOPJAR, N. Radioprotective effects of quercetin and ethanolic extract of propolis in gamma-irradiated mice. Archives of Industrial Hygiene and Toxicology, v.60, p.129-138, 2009. http://dx.doi.org/10.2478/10004-1254-60-20091908 
BHATTACHARYYA, A.; CHOUDHURI, T.; PAL, S.; CHATTOPADHYAY, S.; DATTA, G. K.; SA, G. AND DAS, T. Apoptogenic effects of black tea on Ehrlich's ascites carcinoma cell. Carcinogenesis, v. 24, n.1, p. 75-80, 2003. http://dx.doi.org/10.1093/carcin/24.1.75

BIRKEDAL-HANSEN, H. AND TAYLOR, R. E. Detergent activation latent collagenase and resolution of its molecules. Biochemical and Biophysical Research Communications, v. 107, p. 1173-1178, 1982.

http://dx.doi.org/10.1016/S0006-291X(82)80120-4

CHATTERJEE, S.; BISWAS, G.; CHANDRA, S.; SAHA, G. K. AND ACHARYA, K. Apoptogenic effects of Tricholomagiganteum on Ehrlich's ascites carcinoma cell. Bioprocess and Biosystems Engineering, v. 36, p. 101-107, 2013. http://dx.doi.org/10.1007/s00449-012-0765-6

CHOI, Y. H.; CHOI, W. Y.; HONG, S. H.; KIM, S. O.; KIM, G. Y.; LEE, W. H. AND YOO, Y. H. Antiinvasive activity of sanguinarine through modulation of tight junctions and matrix metalloproteinase activities in MDA-MB-231 human breast carcinoma cells. Chemico-Biological Interactions, v. 179, p. 185-191, 2009. http://dx.doi.org/10.1016/j.cbi.2008.11.009

DAVIS, B. J. Disc electrophoresis. II. Method and application to human serum proteins. Annals of the New York Academy of Sciences, v. 121, p. 404-427, 1964. http://dx.doi.org/10.1111/j.1749-6632.1964.tb14213.x

FREIMOSER, F. M.; JKOB, C. A.; AEBI, M. AND TUOR, U. The MTT [3, (4,5)-Dimethylthiazol-2-yl) -2, 5 - Diphenyltetrazolium bromide] assay is a fast and reliable method for colorimetric determination of fugal cell densities. Applied and Environmental microbiology, v. 65, p. 3727-3729, 1999.

GHOBRIAL, I. M.; WITIZIG, T. E. AND ADJEI, A. A. Targeting Apoptosis Pathways in Cancer Therapy. CA: A Cancer Journal for Clinicians, v. 55, p. 178-194, 2005. http://dx.doi.org/10.3322/canjclin.55.3.178

GROSSMAN, J. H. AND MCNEIL, S. E. Nanotechnology in cancer medicine. Physics Today, v. 65, p. 38-42, 2012. http://dx.doi.org/10.1063/PT.3.1678

GUPTA, M.; MAZUMDER, U. K.; KUMAR, R. S. AND KUMAR, T. S. Antitumor Activity and Antioxidant Role of Bauhinia Racemosa against Ehrlich Ascites Carcinoma in Swiss Albino Mice. Acta Pharmacologica Sinica, v. 25, p.1070-1076, 2004. http://dx.doi.org/10.1007/s10555-010-9235-2

GUPTA, S. C.; KIM, J. H. AND PRASAD, S. Regulation of survival, proliferation, invasion, angiogenesis, and metastasis of tumor cells through modulation of inflammatory pathways by nutraceuticals. Cancer and

Metastasis Reviews, v. 29, p. 405-434, 2010.

HANAFI, N. Role of Chitosan Nanoparticles in Targeting Ehrlich Tumor Cells Transplanted in Albino Mice. International Journal of Research in Biological Sciences, v. 2, p. 6-17, 2012. http://dx.doi.org/10.3923/jbs.2010.468.479

HANAFI, N. AND MANSOUR, S. Z. Antitumor Efficacy of Salenostemma Argel and/or $\gamma$-Irradiation against Ehrlich Carcinoma. Journal of Biological Sciences, v. 10, p. 468-479, 2010

JAKOVLJEVIĆ, Z. D.; STANKOVIĆ, S. M. AND TOPUZOVIĆ, D. M. Seasonal variability of chelidonium majus 1. Secondary metabolites content and antioxidant activity. Experimental and Clinical Sciences International online journal, v. 12, p. 260-268, 2013.

KIM, B. R.; JEON, Y. K. AND NAM, M. J. A mechanism of apigenin induced apoptosis is potentially related to anti-angiogenesis and antimigration in human hepatocellular carcinoma cells. Food and Chemical Toxicology, v. 49, p. 1626-1632, 2011. http://dx.doi.org/10.1016/j.fct.2011.04.015 
KITADA, S.; KRAJEWSKI, S.; MIYASHITA, T.; KRAJEWSKA, M. AND REED, J. C. (). Gamma-radiation induces upregulation of Bax protein and apoptosis in radiosensitive cells in vivo. Oncogene, v. 12, p.187-192, 1996.

LAWRENCE, T. S.; TEN-HAKEN, R. K. AND GIACCIA, A. Principles of Radiation Oncology. In: DeVita VT Jr., Lawrence TS, Rosenberg SA, editors. Cancer: Principles and Practice of Oncology. $8^{\text {th }}$ Ed. Philadelphia: Lippincott Williams and Wilkins, 2008.

LIVAK, K. J. AND SCHMITTGEN, T. D. Analysis of Relative Gene Expression Data Using Real-Time Quantitative PCR and the 22 DDCT. Methods, v. 25, p. 402-408, 2001.

http://dx.doi.org/10.1006/meth.2001.1262

MAZIA, D.; BREWER, P. A. AND AFFERT, M. The cytochemical staining and measurements of protein with mercuric bromophenol blue. Biol Bull, v.104, p. 57-67, 1953. http://dx.doi.org/10.2307/1538691

NADOVA, S.; MIADOKOVA, E.; ALFOLDIOVA, L.; KOPASKOVA, M.; HASPLOVA, K.; HUDECOVA, A.; VACULCIKOVA, D.; GREGAN, F. AND CIPAK, L. Potential antioxidant activity, cytotoxic and apoptosis-inducing effects of Chelidonium majus L. extract on leukemia cells. Neuroendocrinology Letters, v. 29, p. 649-652, 2008.

O’REILLY, M. S.; BOEHM, T.; SHING, Y.; FUKAI, N.; VASIOS, G.; LANE, W. S.; FLYNN, E.; BIRKHEAD, J. R.; OLSEN, B. R. AND FOLKMAN, J. Endostatin: an endogenous inhibitor of angiogenesis and tumor growth. Cell, v. 88, p. 277-285, 1997. http://dx.doi.org/10.1016/S0092-8674(00)81848-6

PARK, S. W.; KIM, S. R.; KIM, Y.; LEE, J. H.; WOO, H. J.; YOON, Y. K. AND KIM, Y. I. Chelidonium majus L. extract induces apoptosis through caspase activity via MAPK-independent NF- $\kappa$ B signaling in human epidermoid carcinoma A431 cells. Oncology Reports, v. 33, p. 419-24, 2015.

PEARSE, A. G. E. Histochemistry, theoretical and applied (4 ${ }^{\text {th }}$ ed.), vol. 2 Churchill, Ltd., London, 1985.

SALAH, E. Evaluation of cytotoxicity on antitumor activity of Curcumin via triggering apoptosis.

Biochemistry Department, Faculty of Vet. Med. Moshtohor, Benha University, Egypt. 2011.

SINGH, P. N.; MCCOY, M. T.; TICE, R. R. AND SCHNEIDER, E. L. A simple technique for quantitation of low levels of DNA damage in individual cells. Experimental Cell Research, v. 175, p. 184-191, 1988. http://dx.doi.org/10.1016/0014-4827(88)90265-0

SU, X. Y.; LIU, P. D.; WU, H. AND GU, N. Enhancement of radiosensitization by metal-based nanoparticles in cancer radiation therapy. Cancer Biology and Medicine, v. 11, p. 86-91, 2014.

SUN, Y., MA, S.; ZHOU, J.; YAMOAH, A. K.; FENG, J. Q.; HINTON, R. J. AND QIN, C. Distribution of small integrin-binding ligand, N-linked glycoproteins (SIBLING) in the articular cartilage of the rat femoral head. Journal Histochemistry Cytochemistry, v. 58, p. 1033-1043, 2010.

http://dx.doi.org/10.1369/jhc.2010.956771

TEERDS, K. J. AND DORRINGTON, J. H. Immunolocalization of transforming growth factor alpha and luteinizing hormone receptor in healthy and atretic follicles of the adult rat ovary. Biology of Reproduction, $v$. 52, p. 500-508, 1995. http://dx.doi.org/10.1095/biolreprod52.3.500

WAJANT, H.; PFIZENMAIER, K. AND SCHEURICH, P. Tumor necrosis factor signaling. Cell Death and Differentiation, v. 10, p. 45-65, 2003. http://dx.doi.org/10.1038/sj.cdd.4401189

ZAREI, A.; CHANGIZI-ASHTIYANI, S.; REZAEI, A.; SHEIDAEE, H. AND NABIYONI, F. The Effect of Chelidonium majus Extract on the Lipid Profile and Activity of Pituitary-Gonadal Axis in Hypercholesterolemic Rats. Zahedan Journal of Research in Medical Sciences, v. 6, p. 18-22, 2014. 